\title{
The 2020 Presidential Election in Belarus: Erosion of Authoritarian Stability and Re-politicization of Society
}

\author{
Sofie Bedford* (1) \\ Institute for Russian and Eurasian Studies, Uppsala University, Sweden \\ *Corresponding author. Email: sofie.bedford@ires.uu.se
}

\begin{abstract}
On August 9, 2020, presidential elections were held in Belarus. Despite blatant electoral fraud and procedural violations, the official results declared Aleksandr Lukashenka reelected for a sixth term. While in the past, even the most obviously fraudulent election results have been followed by an atmosphere of resigned acceptance, this time countless Belarusians took to the streets to contest the results. What made this election different? This analysis of current affairs looks at the 2020 events through the lens of authoritarian consolidation theory, suggesting the unprecedented political mobilization was enabled by erosion in the three pillars of authoritarian stability: repression, cooptation, and legitimation. A majority of the population had been accepting the political status quo out of fear, for social and monetary security provided in exchange for loyalty, or a general understanding that there were no alternatives. Lukashenka did not realize this had largely changed. Nine months later, the foundation of the authoritarian regime is in an even worse shape. The regime's reliance on repression further counteracts the legitimacy of the system. As a result, it seems it will be difficult for the authorities to re-consolidate authoritarianism, at least in the near future, no matter how the 'revolution' unfolds.
\end{abstract}

Keywords: Belarus; protests; post-Soviet; mobilization; authoritarian consolidation

Belarus is often referred to as the last dictatorship in Europe. This definition is both theoretically and empirically questionable, yet it is irrefutable that until 2020 the authoritarian regime of Aleksandr Lukashenka had ruled for the past 26 years without major challenges. Yet Belarus has also been presented as an unusual type of authoritarian state, where the citizens actually like their dictator (McAllister and White 2016). The popular political mobilization that started in connection to the 2020 presidential election was therefore a surprise. When more than 60,000 people gathered in Minsk's Park of Peoples' Friendship on July 30, 2020, to support the election campaign of Svyatlana Tsikhanouskaya, it was possibly the largest political event in Belarus since 1991. Amazingly, within two weeks this record was already broken as allegedly as many as 200,000 people met at the Stella square in Minsk to contest the official election results, according to which Lukashenka had won 80 percent of the popular vote, and Tsikhanouskaya received 10 percent. Six months later, countless Belarusians were still coming out on the streets to protest against the fraudulent election and subsequently against Lukashenka's presidency. After two failed attempts at electoral revolutions in 2006 and 2010, nobody really expected the Belarusian society to muster this level of mobilization. It is not the first time elections were not free and fair, but it is the first time that a large part of the population has openly reacted to it. Even though some marginalized groups, such as the traditional opposition, have in the past taken the opportunity to publicly demand reforms in the context of falsified results, most of the time, elections, no matter how

\footnotetext{
(C) The Author(s), 2021. Published by Cambridge University Press on behalf of Association for the Study of Nationalities. This is an Open Access article, distributed under the terms of the Creative Commons Attribution licence (http://creativecommons.org/licenses/by/4.0/), which permits unrestricted re-use, distribution, and reproduction in any medium, provided the original work is properly cited.
} 
fraudulent the reporting of results, have been followed by an atmosphere of resigned acceptance. This time was different. Not only in Minsk, but also in cities, towns, and even villages all over the country, Belarusians took to the streets to openly show their desire for change. Many of them had no history of political activism (Krawatzek and Sasse 2021).

By looking through the lens of authoritarian consolidation theory, my analysis of these recent events seeks to shed some light on how the sudden political mobilization of the Belarusian population developed. In brief, the theory suggests the authoritarian political system survives and prospers mainly because its citizens let it happen-as a result of their political apathy and resigned acceptance (Gel'man 2010, 56). At the same time, this is possible only because of "a number of interdependencies between the ruler and the ruled" (Gerschewski 2013, 18). According to the theory, the stability of the authoritarian regime rests on its successful use of three categories of strategies, both carrots and sticks, to make the people accept the political status quo: repression (the use of coercion and threats), cooptation (providing benefits to certain groups to convince them not to question the system), and legitimation (getting people to justify, accept, or at least tolerate the current regime) (Gerschewski 2013). Belarus was a truly consolidated hegemonic authoritarian regime. A majority of the population was accepting of the political status quo despite being acutely aware of the lack of democratic standards in their society. This was the result of fear of repression; cooptation in the form of a social contract providing them a basic level of social and financial stability in exchange for loyalty; and a general understanding there were no political alternatives, which made Lukashenka's rule indirectly legitimate. In retrospect, the unprecedented political mobilization of 2020 seems to have been enabled when these strategies became ineffective.

In what follows, I provide a short overview of the 2020 presidential election and its aftermath. I then discuss how, as a result of both long-term processes and more sudden developments, the authoritarian strategies became inefficient in sustaining the long-standing political apathy and resigned acceptance of the population that kept the regime securely in power. Finally, I briefly consider the impact of this development on the Belarusian society.

\section{A Remarkable Election and its Aftermath}

When the Belarusian leaders decided not to postpone the August 2020 presidential election, despite the fact that doing so would have been entirely reasonable in the midst of the ongoing global Coronavirus pandemic, they made a fatal mistake. They expected that Lukashenka would be reelected for the fifth time in the usual order. But they were wrong. The first sign that something was different appeared when the candidates were in the process of collecting the 100,000 signatures needed to register their candidacy. Usually this is a tedious process, but this time, people all over the country were lining up in unprecedented numbers to express their support for the campaigns of three political newcomers: Viktar Babaryko, the former chairman of the board of Belgazprombank; Valery Tsapkala, former Belarusian ambassador to the United States and the founder of High Technologies Park in Minsk; and well-known video blogger Syarhei Tsikhanouski. All three, but especially Tsikhanouski, with a campaign called "Stop the Cockroach," quickly became vastly popular. Not surprisingly, he was soon arrested on bogus charges, leaving his wife Svyatlana to register in his place.

Babaryka and Tsapkala were eventually barred from contention-their candidacies were not accepted even though they had collected the required number of signatures. Babaryka was later imprisoned, clearly on false charges. Svyatlana Tsikhanouskaya was, surprisingly, allowed to stay in the presidential race, which is curious since the collection of signatures had made it explicitly clear that she enjoyed large support among the population. One theory is that Lukashenka's administration most likely underestimated her because she was a woman. Perceived as a harmless stay-athome-mom with no prior political experience, previously working as a teacher, they mistakenly thought she would not be able to capitalize on this popular support. Perhaps she would not have been able to on her own, but after failing to register their candidacies Babaryka and Tsapkala's teams officially joined her. This is when the Tsikhanouskaya phenomenon really took off. 
Suddenly, the challenge to Lukashenka's rule became visual and tangible through the joint efforts of three women: Tsikhanouskaya, Veronica Tsapkala (Tsapkala's wife), and Maria Kolesnikova (Babaryka's campaign manager). Somehow, these women and this campaign came to embody a glimpse of hope for change, something most Belarusian had started to think they would never experience. The election campaign exposed the fact that there were a lot more Belarusian wanting change than anyone expected. There was an extraordinary number of electoral activities taking place both online and offline. Especially striking were the large numbers of Belarusians who previously were apathetic about elections and politics but who were now taking part in these activities during what has been called a "summer of protests." A record number of people joined prodigious electoral rallies all over the country in support of Tsikhanouskaya. Eventually, the authorities put a stop to these assemblies using a variety of excuses.

This astonishing electoral participation persevered on Election Day. In an attempt to make it more difficult to falsify the results, Tsikhanouskaya's supporters had been encouraged to vote as late as possible. Thus, toward the evening, long lines to the polling stations began to form in numerous Belarusian cities and abroad, in front of embassies. Several of those waiting were wearing a white bracelet-a symbol of Tsikhanouskaya's campaign. Of course, at the end of the day, Lukashenka was still declared the winner. There were no independent international election monitors present, and in many cases, national monitors were not even allowed inside the voting locations - the official reason given being the Coronavirus pandemic. Still, there is no doubt massive election fraud was, as usual, conducted. The fact that many polling stations closed while voters were still lined up outside is just one indication of voter suppression; myriad other additional violations were reported. Data from the various platforms where Tsikhanouskaya's voters were asked to register their vote, such as Golos [Voice], Zubr, Tjestnye Liudi [Honest People], show both that Lukashenka could not possibly have received 80 percent of the votes and that Tsikhanouskaya was likely to have the support of a majority (Rudnik 2020; Voice of Belarus 2020).

Previous election protests in Belarus were relatively small-scale, both in terms of number of participants and in geographical spread and could therefore also be easily resolved through brutal police intervention. This time, however, the election results were questioned in many different places across the country and the protesters were unwavering. Large-scale protest marches were held every weekend in both Minsk and other cities, but the number of participants decreased significantly from around 200,000 at the height of the protests to several thousand in December 2020 (Onuch 2020). Additionally, the mobilization was not centralized in the same way it was during previous election protests. No attempts were made to build a tent camp in central locations à la Maidan. Instead, the protesters were inspired by the protest movement in Hong Kong and strived to have activities in many different places at the same time to make it more difficult for the police to focus resources and stop their development.

In addition to marches and demonstrations, a number of other activities-both collective and individual-evolved, often highlighting the white-red-white flag in different situations. The development generated a large number of self-organized protest groups operating in neighborhoods, universities, or workplaces. The groups regularly carry out local protest activities, and many have even designed their own logos and protest flags. Because of the continuous harassment and arrests, the character of dissent gradually transformed from major public protest to an eclectic civil resistance movement. Despite this, the protest spirit among the population still, nine months after the election, appears strong.

\section{The End of Popular Cooptation: Whither the Social Contract?}

\section{Struggling Economy and Lack of Reforms}

The most commonly heard explanation for the Belarusian system surviving and prospering for more than 26 years is its reliance on a sort of co-optation-a Soviet-style social contract between Lukashenka and his citizens that guarantees them stability, order, and financial security in exchange 
for their loyalty. Thus, the social contract is "an implicit agreement between the state and the main social groups, in which parties are more or less aware of the costs and benefits of their behavior" (Haiduk 2009, 9). As various population groups have different needs, the benefits provided differed, but largely the contract provided "opportunities to find a job, offered a wide range of complimentary services and subsidized some prices and tariffs" (Dobrinksy 2016, 10).

This system was based primarily on incomes from heavily subsidized natural gas and crude oil from Russia, which made it possible both to run domestic industry cheaply and to generate revenue by re-exporting refined oil products to Western Europe. The global financial crisis, a deteriorating Russian economy due to the sanctions resulting from the occupation of Crimea, and falling oil prices have had a major impact on the socioeconomic situation in Belarus and subsequently on the state's ability to provide the same level of welfare and financial stability for its population as before. Previously, GDP per capita has increased steadily, but during 2014-2019, growth was zero percent (Guriev 2020, 274). The 2015-2016 recession hit the country particularly hard. Real incomes fell significantly, and more households were classified as low-income groups, indicating that the population became more vulnerable to poverty (Bornukova et al. 2019; Shymanovich 2017). Even now, average wages have not increased and income disparities between Minsk and other regions have grown. Pension payments have also stagnated and not increased in line with constant inflation. Most pensioners do not have to live in extreme poverty but, importantly, do not have the same high standard of living they had before (Douglas, 2020).

\section{Security Instead of Welfare}

Officially marketed as a response to the Ukraine crisis, but most likely responding to the country's economic difficulties, Lukashenka was trying to introduce a security contract guaranteeing citizens' national independence and safety, rather than primarily social and financial benefits. Research has suggested there was little evidence that the population endorsed this rebranding (Wilson 2016). This is not surprising, for in reality it seemed to mean more funds went to state-sector employees, particularly members of the security apparatus, than into strengthening the social welfare sector (Douglas 2020). Overall, there were fewer and fewer resources to maintain the extensive general social and welfare policies that were the backbone of the social contract (Pranevičiūtè-Neliupšiene and Maksimiuk 2012). Attempts to reform the social security system in response to internal and external challenges have led nowhere, and the current system has been described as "fragile and miserable" (Chulitskaya and Matonyte 2018, 543). It was inevitable that as the so-called father of the country Lukashenka would be blamed for this. Many analysts pointed out that the reason he did not implement the reforms necessary to strengthen the economy was that they would have weakened his own position (see, for example, Astapenia 2020; Kłysiński 2016). It has even been suggested that Lukashenka refused change because he personally thinks that market economy is ideologically unacceptable (Moshes and Nizhnikau 2019). When they decided to hold the 2020 presidential election under the prevailing conditions, the Belarusian leaders did not seem to understand that the social contract was no longer working to protect the regime in the same way. There was also a fear the economic situation would get even worse in the future given the instable relation with Russia and insecure future of energy subsidies. Many people had already seen their personal financial situation deteriorate and at least to some extent blamed Lukashenka for this.

It was in this context President Lukashenka's response to the COVID-19 crisis became the straw that broke the camel's back. To avoid putting more stress on the already weak economy, Belarusian leaders chose to keep society open during the pandemic. Moreover, by joking and calling the pandemic a "psychosis," Lukashenka told the Belarusian people he was not taking it seriously. While he was telling his citizens to drink vodka and drive tractors to stay safe, they wanted strong state measures as they saw the virus and its effects as an actual threat. The president's decision to go against the stream and not cancel the annual Victory Day Military Parade when most other postSoviet states were doing so (the only other exception being Turkmenistan) signaled to many he 
cared more about his own prestige than about protecting the innocent old people who are particularly vulnerable to this disease. After this event, even more Belarusians seemed to be openly skeptical of their government's approach to the crisis. The fact the authorities were perceived as ignoring the situation gave rise to vast community mobilization. Volunteers were not only producing masks but also collecting an enormous amount of material and money through various citizen initiatives to support health care workers and others fighting the virus. The already defunct social contract became completely invalid. It was not so much because people felt they were not being supported financially but rather about not being able to trust the government to care about your well-being at all. They had to take matters in their own hands simply because they could no longer count on their president and his administration. It was truly unfortunate for Lukashenka this happened during an election year.

\section{Legitimation Strategies in Question when Society Changes \\ Changing National Myth and Less Obvious Adversaries}

Autocracies try to create perceptions of legitimacy for their political order based on an idea of what the regime actually is or represents, such as the political ideologies, religion, nationalism, or the qualities of a specific leader (Gerschewski 2013; Holbig 2013). In Belarus, this was most obvious in the narrative about Lukashenka as Bat'ko, "the little father," an honest "master of the house" who rules his country with a firm hand (Rudling 2017, 88). One important way that Lukashenka has legitimized his current political order is through juxtaposing it against the political opposition. By highlighting the failure of the opposition to achieve change and portraying it as a threat to the stability ensured by the current regime, the authorities justified Lukashenka's continued dominance of the state. It worked. Ronan Hervouet (2013) notes that many considered the opposition actors themselves to blame for the repression they often faced. They were seen as troublemakers who kept insisting on challenging the regime even though they (as did everyone else) knew it would cause problems.

Importantly, the opposition was constructed as threatening not only the political order but also national identity. In the official nation-building project the Belarusian Soviet Socialist Republic was the foundation and the Belarusian national identity intertwined with the Russian (Bekus 2010, 282). This was contrasted with the version of the Belarusian nationalists in general and the Belarusian People's Front Party in particular, which presented the Soviet experience as a parenthesis and instead believed that the short-lived Belarusian People's Republic, or Belarusian National Republic (BNR), of 1918-1919 was central for Belarusian nation building (Rudling 2017, 79). It was unfortunate that the political opposition's struggle against the authoritarian regime became so closely linked to the struggle for Belarusian identity. Grigory Ioffe (2003) describes the oppositional nationalists as arrogant, trying to impose a Belarusian national identity that never really existed. By, for example, insisting that speaking Belarusian was the only way to be Belarusian, the nationalist opposition scared away the majority of the people, who preferred to speak Russian. As noted by Fabian Burkhardt $(2016,165)$, oppositional actors put forward different concepts of nation. BPF's ethno-cultural concept was, in fact, only one of these. Still, according to the discourse of the Belarusian authorities this was all "bad nationalism," in contrast to the "good nationalism" promoted by the state actors (Bekus 2010, 623).

Things had been changing in recent years. Lukashenka started to emphasize and promote the Belarusian language and culture in various ways and even introduced parts of the BNR legacy into its rhetoric. This development seemed to have made the identity aspect of opposition less intimidating. The Belarusian language and identity issues were no longer perceived as particularly controversial. According to Arkady Moshes and Ryhor Nizhnikau, Belarusian was becoming "more trendy and ... no longer associated with 'backwardness' and a lack of education or viewed merely as a marker of belonging to political opposition" $(2019,5)$. This "soft Belarusianization" has both been 
described as an attempt to withdraw from Russia when Lukashenka wanted to improve relations with the European Union (Rudkouski 2017) and a way to make the regime more politically legitimate at home without having to deviate from the authoritarian orientation (Rudling 2017). It could, however, be suggested it also took away from Lukashenka's legitimacy as he was no longer the sole guarantor and protector of the Belarusian national idea.

\section{An Archaic President versus a Modernizing Population}

At the same time, there were indications that the outdated and static system Lukashenka represented was losing legitimacy among the younger population in general. Nadja Douglas (2020) notes the president angered young people in particular by introducing the infamous "parasite law" in 2017 (basically a tax on unemployment), tightening legislation on drug possession, and restricting young men's right to postpone their compulsory military service. An opinion poll conducted in January 2020 found that, unlike the older generation, a large proportion of Belarusians under the age of 45 preferred Western democracy to the current model and also oppose Lukashenka's government (O'Loughlin, Toal, and Bakke 2020). Society was changing, but Lukashenka was oblivious to this dynamic.

It is not yet possible to say whether it is precisely this development that has driven the protest movement. However, the election campaign clearly capitalized on the growing gap between an open-minded population ready for transformation of Belarusian society and an archaic president afraid of change and progress (Moshes and Nizhnikau 2019). Young people especially spread the image of Lukashenka as a president no longer popular who even disgusts the population. He was first described as a "cockroach" by Syarhei Tsikhanouski and later as "Sasha 3\%" after independent Belarusian media published the results of an informal election poll indicating that his support among the population was extremely low. "Psycho 3\%" was another popular reference to his insistence that coronavirus is just a "psychosis." All the memes and other visualization of this mockery were important, as they contributed to further delegitimizing Lukashenka's position by conveying the message that the president's supporters (in contrast to common belief) were in minority and that political change therefore was within reach.

Finally, gender also became an important and integral part of the protest movement. The president's open male chauvinism had already damaged his legitimacy among many women. Lukashenka's habit of trying to diminish women is part of the backwardness no longer accepted by many in the modernizing society. Many women used the campaign to respond to some of his infamous comments and to show that, contrary to what the president believed, Belarusian women considered themselves ready to play a leading role in political participation (Bedford, 2021).

\section{Selective Repression and Controlled Openness}

Until 2020 repression in Belarus primarily took a selective and intermittent form, traditionally targeting the regime's political opponents, civil activists, journalists, and others who are questioning the current system. In individual cases, the political repression has been severe, such as the case of the disappearance of four political activists in 1999 and 2000. Likewise, the crackdowns on postelection protests in 2006 and 2010 in Minsk were brutal and violent.

Mostly, however, Lukashenka's regime has successfully secured the continuity of its rule through neutralizing any potential challenges before they become a real threat, and efficiently marginalizing the political opposition. Because of this the Belarusian authoritarianism has often been described in rather soft terms, such as "preemptive" (Silitski 2009) "adaptive" (Frear 2018), and "pragmatic" (Chulitskaya and Matonyte 2018, 543). Thus, when the European Union was warming up to Lukashenka's regime after the Ukraine crisis, wanting to initiate a dialogue about lifting sanctions and negotiating a visa liberalization program, the authorities were pragmatic. They avoided the use of imprisonment or direct violence against opposition-minded and even released all remaining 
political prisoners in 2015 (in return for which, the Council of the European Union abolished most of its sanctions).

This pragmatic approach provided a certain "controlled openness," which meant that to a degree activism and civic participation was possible-as long as it was not directly and explicitly political (Bedford 2017). Part of the population actively engaged in various types of activities-within, for example, academia, the cultural sphere, and environmental movements. Clearly, the Belarusians were not passive, even though they did not participate in politics. Their engagement instead took place in a social gray zone, where the organizers and participants neither fully accepted nor officially questioned the state discourse (Ackermann, Berman, and Sasunkevich 2017). Some argue that the controlled openness was less about pragmatism than lacking resources to control and repress all part of society. In any case, allowing this room for maneuvering seems to have made the regime more vulnerable. It appears that the controlled openness laid the foundation for the activism, commitment, and initiative that became the driving force for the 2020 protests. As Anton Dinerstein $(2019,51)$ has noted many of those involved in public creative events were forced into a social reality they personally did not accept. The presidential election became their chance to actively try to change it.

\section{Re-politicization Following the Erosion of Authoritarian Stability}

Over more than 25 years, the authoritarian regime in Belarus had become deep-rooted in the political system. As outlined above, this was not necessarily because people were particularly loyal to the regime. Rather it was a result of the interdependencies established between the people and the system through co-optation, a construction of the authoritarian regime (and Lukashenka in particular) as legitimate rulers, and selective repression against anyone engaged in public political activity. The success of these authoritarian strategies was largely ensured by the regime managing to establish a discourse and practice of politics that favored the status quo of the current system. Politics became largely perceived as somebody else's business, as something unnecessary and irrelevant, and as such of little interest to most. This was an important reason the authoritarian regime has survived for so long. "When politics does not matter, changing the government becomes a non-matter and the system is safe" (Bedford 2017, 404).

One of the few explicit reasons stated for political apathy is the belief (true or false) that there are no alternatives to existing arrangements. People in general might not have supported Lukashenka, but they did not trust the political opposition, either, seeing it as more symbolic than relevant. Year after year, oppositional actors participated in an election game, they knew they would lose. Plus, their political agenda was unattractive to a large part of the population who did not identify with the oppositional version of Belarusianness, which focused intensely on "the promotion of the Belarusian language and Belarusian ethnic and national identity in its anti-Russian mode" (Bekus, 2010, 613). It was in the light of this the candidacies of Syarhei (and later Svyatlana) Tsikhanouski, Babaryka, and Tsapkala met with such enthusiasm. Neither of them was perceived as oppositional in the conventional sense, and they were therefore seen as more credible and worthy contenders. Probably the atmosphere of activism and mobilization that gripped society in relation to the COVID-19 pandemic also contributed to their starting to think that these three candidates even posed a realistic challenge to Lukashenka.

Moreover, one of the reasons for Svyatlana Tsikhanouskaya's popularity was that she did not have the national identity as her main focus. She almost always spoke Russian in her appearances and can be said to represent a Russian-speaking Belarusian national identity (Fabrykant 2019). Although Tsikhanouskaya of course emphasized that Belarus is an independent country, the geopolitical agenda was conspicuously absent both during her campaign and during the protests that have followed, where focus has been on free elections and democracy, not about choosing between Russia and Europe (Kazharski 2021, 75). Interestingly, the movement has appropriated the white-red-white flag, which was traditionally the trademark of the political opposition. From 
representing a marginalized elite group fighting a losing battle against the regime under the banner of nationalism, the flag is now seen as a symbol of countrywide popular resistance against the authoritarian system. As such, it is firmly rooted in grassroots activism and now lacks its previous ethno-cultural associations (Kazharski 2021, 75-76). This change is a significant illustration of a massive re-politicization of the Belarusian society that has taken place.

\section{What Have We Learned So Far?}

Although the development in Belarus came as a surprise to most, the academic literature on authoritarian consolidation helps us, in retrospect, better understand what factors contributed to the unprecedented societal mobilization and politicization process that started in connection to the 2020 presidential election. It helps explain how, in the years leading up to this point, the main strategies on which Belarusian authoritarianism had previously relied-cooptation, legitimation, and repression-lost their efficiency. A look at the developments after the election suggests that even though Lukashenka (at the time of this writing, some nine months after voting day) still refuses to compromise or leave his position, his authoritarian regime has nevertheless suffered heavy defeats. The developments in Belarus highlight in particular how vulnerable an authoritarian regime becomes when its legitimacy is openly questioned. Today, many in the population no longer accept the continuation of the status quo and Lukashenka's presidency, and they continue to publicly and creatively express their desire for change.

Cooptation of some important groups still seems to work for Lukashenka's regime: for example, the police, military, and special forces continue to largely stand dutifully by his side. As a result, the regime can continue to use repression to control the situation. Between the beginning of 2020 and the end of March 2021, 30,000 individuals were detained, primarily participants in peaceful rallies and people accused of holding "one-person pickets by displaying national symbols on the windows and facades of their private homes." (Human Rights Center Viasna 2021, 6). Police have used excessive force on the streets. Many of those detained have since been prosecuted and imprisoned. A large number of those arrested testify to torture (Human Rights Watch 2021). However, repression alone is rarely enough to efficiently sustain an authoritarian system (Guriev and Treisman 2015), and it is also clear in the Belarusian case that the government's aggressive approach does not seem to have had the desired impact. In fact, the initial erratic violence against protesters brought to mind a whack-a-frog game and indicates that the authoritarian system does not seem to know exactly how to handle the situation when selective repression no longer works.

Moreover, the state's harsh reaction to the protests after the election further damaged Lukashenka's legitimacy in the country. Before this, many did not actually believe their president would resort to this level of violence against his own citizens just to protect his position. The video released in September 2020 showing hundreds of workers at the MZKT tractor factory in Minsk cheering and shouting "Retire!" and "Disappear!" (ukhodi) provides an interesting illustration of the fact that Lukashenka can no longer fully rely on the support of his previous core supporters (Scollon 2020). According to a December 2020 survey, as many as 80 percent of the protesters at that point said that it was seeing the state violence against peaceful citizens that convinced them to get involved (Krawatzek and Sasse 2021).

For some time, those who could possibly be seen as leaders of the protest movement-the board members of the Coordination Council created to eventually lead negotiations with Lukashenka on the transfer of power-were specifically targeted. Several of them have been arrested, and the rest, including Tsikhanouskaya, forced to flee the country. Since the protest movement has been largely leaderless-neither Tsikhanouskaya nor either of the other two women who led the election campaign have taken on a central role-the removal of the Council's leader did not put an end to dissent. The relentless harassment of protesters toward the end of 2020, in combination with the arrival of winter, however, appears to have ended the major weekend marches in Minsk and other cities, at least temporarily (Onuch 2020). At the same time, the protest spirit is still strong in the 
country, and the dynamic and decentralized nature of the resistance makes it difficult for the regime to completely stop the process.

A number of recent events, like the raid and closure of the independent news agency TUT.by (Current Time, 2021), seem aimed at preventing the population's access to information. The authorities likely foresee a deterrent effect as well, by arresting many of the journalists. The forced landing of a commercial plane carrying journalist Raman Pratasevich (Troianovski and Nechepurenko, 2021) similarly indicates the regime striving to control the situation by removing actors from the public space who they believe are feeding the resentment. Pratasevich, who was detained after the plane was forced down in Minsk, was the founder of the NEXTA Telegram channel, an important information and coordination tool for the protesters (Herasimenka, Lokot, Onuch and Wijermars, 2020),

Not only has Lukashenka lost his previous popularity among many sectors of the population, but the internal processes have also affected the authoritarian regime's standing in the international community. The election result is not recognized by the European Union (Council of the European Union, 2020) and many European leaders refuse to accept his presidency (Joint Statement of Nordic-Baltic Foreign Ministers [...] 2020), which suggests that the regime's claims for international respect and legitimacy are in flux. The regime also risks becoming increasingly isolated. After the recent incident with Pratasevich, European Union leaders quickly agreed on sanctions against Belarus, including banning the national airline Belavia from using their countries' airspace and airports (Euronews, 2021).

Political change in Belarus is not likely to happen overnight, but the observed explosive increase in political participation and civic activism is a positive sign. The authoritarian state was maintained by most people's accepting the authoritarian status quo and considering politics as somebody else's problem. Now, despite a lack of formal achievements, the protest movement has contributed to a more politically conscious and outspoken society. In this respect, even though Lukashenka is still in power, the political status quo has already changed for the better. Unless his goal is a North Koreastyle dictatorship, Lukashenka will, sooner or later, have to take some kind of action to try to restore the democratic façade. Whether it is implementing the constitutional changes that he has long promised or holding new elections, the politicization of society is likely to make it difficult, if not impossible, for him to use these measures to restore the legitimacy and stability that characterized his authoritarian regime.

It is unlikely that those who took part in the protests will ever again accept the election game in its previous form. In addition, attempts have been made to build a credible political alternative, based on the protest movement (Polish News 2020). Developments in Belarus are often described as closely linked to the interests of Russia. Of course, in the eyes of the Kremlin it would not set a good example for the Russian opposition if the authoritarian regime in Belarus collapsed due to the pressure of the demonstrators. Still, many analysts suggest that Putin is growing increasingly tired of Lukashenka and his antics and is looking for a suitable and acceptable successor (EurActiv 2020; Rainsford 2020). If, during some sort of state-instigated transformation exercise a new political platform managed to put forward a candidate that both the Belarus society and Russia can accept, it could potentially lead to democratization "by mistake" (Treisman 2017)—or at least result in the start of a process of genuine institutional change, even if it was not Lukashenka's intention.

Acknowledgments. I thank the anonymous reviewer for insightful feedback.

Disclosures. None

Note

1 Some sections of the text have previously been published as online commentaries by Baltic Worlds (Bedford 2020a, 2020b). 


\section{References}

Ackermann, Felix, Mark Berman, and Olga Sasunkevich. 2017. "In Search of Agency: Examining Belarusian Society from Below." Journal of Soviet and Post-Soviet Politics and Society 3 (1): 1-18.

Astapenia, Ryhor. 2020. "Lukashenka's Commitment to Belarusian Sovereignty Is Overstated. Chatham House. February 18, 2020. https://www.chathamhouse.org/2020/02/lukashenkas-commitment-belarusian-sovereignty-overstated. (Accessed February 10, 2021.)

Bedford, Sofie. 2017. “The Election Game': Authoritarian Consolidation Processes in Belarus.” Democratizatsiya: The Journal of Post-Soviet Democratization 25 (4): 381-405.

Bedford, Sofie. 2020a. “The Covid-19 Pandemic in Belarus: Wither the Social Contract?” Baltic Worlds, June 16, 2020. http:// balticworlds.com/the-covid-19-pandemic-in-belarus-wither-the-social-contract/.

Bedford, Sofie. 2020b. "The Tsikhanauskaya Effect: How an Accidental Heroine Transformed the Belarusian 2020 Presidential Election.” Baltic Worlds, September 7, 2020. http://balticworlds.com/the-tsikhanauskaya-effect/.

Bedford, Sofie. 2021. "Osäkerhetens politik i praktiken: Presidentvalet 2020 som förändrade Belarus" [The Politics of Uncertainty' in Practice: The 2020 Presidential Election that Changed Belarus] Nordisk Østforum, no. 35: 36-59.

Bekus, Nelly. 2010. Struggle over Identity: The Official and the Alternative "Belarusianness." Budapest: Central European University Press.

Bornukova, Kateryna, Alexandru Cojocaru, Mikhail Matytsin, and Gleb Shymanovich. 2019. Poverty, Vulnerability, and Household Coping Strategies during the 2015-16 Recession in Belarus. World Bank Policy Research Working Paper 9003. http://beroc.by/upload/iblock/d76/d7603506057422bc020e4067f42989c9.pdf.

Burkhardt, Fabian. 2016. "Concepts of the Nation and Legitimation in Belarus." In Politics and Legitimacy in Post-Soviet Eurasia, edited by Martin Brusis, Joachim Ahrens, and Martin Schulze Wessel, 148-171. London: Palgrave Macmillan.

Chulitskaya, Tatsiana, and Irmina Matonyte. 2018. "Social Security Discourses in a Non-democratic State: Belarus between Soviet Paternalistic Legacies and Neo-liberal Pressures." Public Policy and Administration/Viešoji politika ir administravimas 17 (4): 539-554.

Current Time. 2021. “Shutdown Of Belarus' Largest Independent News Site Part Of 'War Against Genuine Journalists', Critics Say.” Current Time, May 19, 2021. https://en.currenttime.tv/a/shutdown-of-belarus-tut-by-part-of-war-against-genuinejournalists-critics-say/31263354.html. (Accessed May 26, 2021.)

Euronews. 2021. UN Security Council to hold 'closed door' meeting on Belarus plane diversion. Euronews, May 25, 2021. https:// www.euronews.com/2021/05/25/ryanair-flight-diverted-to-belarus-journalist-arrested-on-arrival. (Accessed May 26, 2021.)

Dinerstein, Anton. 2019. “Cultural Identity in Modern-Day Belarusian Discourse on Public Creativity.” Journal of International and Intercultural Communication 14 (1): 41-59.

Dobrinsky, Rumen. 2016. "Belarus' Unorthodox Political and Economic Transformation." In The Belarus Economy: The Challenges of Stalled Reforms, wiiw Research Report No. 413, edited by Rumen Dobrinsky, 3-42. Vienna: Wiener Institut für Internationale Wirtschaftsvergleiche. https://wiiw.ac.at/the-belarus-economy-the-challenges-of-stalled-reforms-dlp4032.pdf.

Douglas, Nadja. 2020. "Belarus: From the Old Social Contract to a New Social Identity." Centre for East European and International Studies. ZOiS Report 9/11/2020. https://en.zois-berlin.de/publications/belarus-from-the-old-social-contractto-a-new-social-identity.

EurActiv. 2020. “Putin's Unexpected Dilemma: What To Do with Lukashenka?” EurActiv, August 20, 2020. https://www. euractiv.com/section/europe-s-east/news/putins-unexpected-dilemma-what-to-do-with-lukashenko/. (Accessed February 10, 2021.)

Council of the European Union. 2020. Belarus: Declaration by the High Representative on Behalf of the European Union on the So-called "Inauguration" of Aleksandr Lukashenka [Press release], 24 September 24, 2020. https://www.consilium.europa. eu/en/press/press-releases/2020/09/24/belarus-declaration-by-the-high-representative-on-behalf-of-the-european-unionon-the-so-called-inauguration-of-aleksandr-lukashenko/.

Fabrykant, Marharyta. 2019. "Russian-Speaking Belarusian Nationalism: An Ethnolinguistic Identity without a Language?” Europe-Asia Studies 71 (1): 117-136.

Frear, Matthew. 2018. Belarus under Lukashenka: Adaptive Authoritarianism. London: Routledge.

Gel'man, Vladimir. 2010. "Regime Changes Despite Legitimacy Crises: Exit, Voice, and Loyalty in Post-communist Russia." Journal of Eurasian Studies 1(1), 54-63.

Gerschewski, Johannes. 2013. "The Three Pillars of Stability: Legitimation, Repression, and Co-optation in Autocratic Regimes." Democratization 20 (1): 13-38.

Guriev Sergei. 2020. “The Political Economy of the Belarusian Crisis.” Intereconomics: Review of European Economic Policy 55 (5): 274-275.

Guriev, Sergei, and Daniel Treisman. 2015. How Modern Dictators Survive: Cooptation, Censorship, Propaganda, and Repression. Centre for Economic Policy Research. CEPR Discussion Paper No. 10454.

Haiduk, Kiryl. 2009. “Social Contract: A Conceptual Framework.” In Social Contracts in Contemporary Belarus, edited by Kiryl Haiduk, Elena Rakova, and Vitali Silitski, 8-25. Minsk: Belarusian Institute for Strategic Studies. 
Herasimenka, Aliaksandr, Tetyana Lokot, Olga Onuch and Mariëlle Wijermars. 2020. ”There's more to Belarus's 'Telegram Revolution' than a cellphone app." Washington Post, September 11, 2020. https://www.washingtonpost.com/politics/2020/ 09/11/theres-more-belaruss-telegram-revolution-than-cellphone-app/. (Accessed May 26, 2021.)

Hervouet, Ronan. 2013. “Authoritarianism from Below: Lessons from Ethnographic Studies in Belarus. Anthropology of East Europe Review. 31(2): 19-29.

Holbig, Heike. 2013. “Ideology after the End of Ideology: China and the Quest for Autocratic Legitimation.” Democratization 20 (1): 61-81.

Human Rights Center Viasna. 2021. Politically Motivated Administrative Proceedings: Standards and Reality in Contemporary Belarus. http://spring96.org/files/misc/politically_motivated_administrative_proceedings_eng.pdf. (Accessed 19 April 19, 2021.)

Human Rights Watch. 2021. “Belarus: Events of 2020.” In World Report 2021 (online). https://www.hrw.org/world-report/ 2021/country-chapters/belarus. (Accessed February 10, 2021.)

Ioffe, Grigory. 2003. “Understanding Belarus: Questions of Language.” Europe-Asia Studies 55 (7): 1009-1047.

Joint Statement of Nordic-Baltic Foreign Ministers on Recent Developments in Belarus. 2020. August 11, 2020. https:// www.stjornarradid.is/library/04-Raduneytin/Utanrikisraduneytid/PDF-skjol/NB8\%20statement\%20Belarus.pdf. (Accessed April 19, 2021.)

Kazharski Aliaksei. 2021. "Belarus' New Political Nation? 2020 Anti-authoritarian Protests as Identity Building." New Perspectives 29 (1): 69-79.

Kłysiński, Kamil. 2016. "How to Get out of the Crisis without Reforms? The Belarusian Authorities Confront Growing Economic Problems." OSW Commentary, No. 202, March 22, 2016. https://www.osw.waw.pl/sites/default/files/commen tary_202.pdf. (Accessed February 10, 2021.)

Krawatzek, Félix, and Gwendolyn Sasse. 2021. "Belarus Protests: Why People Have Been Taking to the Streets-New Data.” The Conversation, February 4, 2021. https://theconversation.com/belarus-protests-why-people-have-been-taking-to-thestreets-new-data-154494. (Accessed February 10, 2021).

McAllister, Ian, and Stephen White. 2016. "Lukashenka and His Voters." East European Politics and Societies 30 (2): $360-380$.

Moshes, Arkady, and Ryhor Nizhnikau. 2019. "The Belarusian Paradox: A Country of Today Versus a President of the Past." Finnish Institute of International Affairs. FIIA Briefing Paper No. 256. https://www.fiia.fi/wp-content/uploads/2019/06/ bp265_belarusian_paradox.pdf. (Accessed September 17, 2020.)

O’Loughlin, John, Gerard Toal, and Kristin Bakke. 2020. “Is Belarus in the Midst of a Generational Upheaval?” Global Voices (blog), September 17, 2020, https://globalvoices.org/2020/09/17/is-belarus-in-the-midst-of-a-generational-upheaval/. (Accessed February 10, 2021.)

Onuch, Olga. 2020. "Belarus Rises: Four months and Counting." ZOiS Spotlight 46/2020. https://en.zois-berlin.de/publications/ zois-spotlight-2020/belarus-rises-four-months-and-counting/. (Accessed February 10, 2021.)

Polish News. 2020. Belarus. "Wiktar Babaryka wants to form a party. He talks about uniting the opposition," Polish News, September 1, 2020. https://www.polishnews.co.uk/belarus-wiktar-babaryka-wants-to-form-a-party-he-talks-about-unit ing-the-opposition/. (Accessed May 26, 2021.)

Pranevičiūtè-Neliupšienè, Jovita, and Zhanna Maksimiuk. 2012. "Authoritarian Bargain in Belarus: The System of Social Benefits as a Factor of Regime Stability.” Poitologija 68 (4): 106-140.

Rainsford, Sarah. 2020. "Kremlin Looks to Keep Protest-Torn Belarus in Moscow's Orbit.” BBC News, September 15, 2020. https://www.bbc.com/news/world-europe-54155882. (Accessed April 19, 2021)

Rudkouski, Piotr. 2017. "Soft Belarusianisation: The Ideology of Belarus in the Era of the Russian-Ukrainian Conflict.” OSW Commentary, No. 253, November 3, 2017. https://www.osw.waw.pl/sites/default/files/commentary_253-tv.pdf. (Accessed February 10, 2021.)

Rudling, Per Anders. 2017. “'Unhappy Is the Person Who Has No Motherland': National Ideology and History Writing in Lukashenka's Belarus.” In War and Memory in Russia, Ukraine and Belarus, edited by Julie Fedor, Markku Kangaspuro, Jussi Lassila, and Tatiana Zhurzhenko, 71-105. Cham: Palgrave Macmillan.

Rudnik, Lesia. 2020. "Explainer: How Do We Know that Belarusian Election Was Rigged and Who Won The Race? The Center for New Ideas.” Цэнтр новых ідэй. September 1. https://newbelarus.vision/explainer-elections/. (Accessed May 27, 2021.)

Scollon, Michael. 2020. “Lukashenka’s Pleas to Factory Workers Met with Jeers, Not Cheers.” Radio Free Europe/Radio Liberty, August 17, 2020. https://www.rferl.org/a/lukashenka-s-pleas-to-factory-workers-met-with-jeers-not-cheers/30788630. html. (Accessed April 19, 2021.)

Shymanovich, Gleb. 2017. "Bednost' i sotsial'no ujazvimije gruppi naselenija v Belarusi posledstvija retsessii 2015-2016 gg." [Poverty and Socially Vulnerable groups in Belarus in the Aftermath of the Recession]. Issledovatel'skij tsentr IPM. http:// kef.research.by/webroot/delivery/files/poverty2017.pdf.

Silitski, Vitali. 2009. “Contagion Deterred: Preemptive Authoritarianism in the Former Soviet Union (the Case of Belarus).” In Democracy and Authoritarianism in the Postcommunist World, edited by Valerie Bunce, Michael McFaul, and Kathryn Stoner-Weiss, 274-299. Cambridge: Cambridge University Press.

Treisman, Daniel. 2017. “Democracy by Mistake.” National Bureau of Economic Research. NBER Working Paper No. 23944. http://www.nber.org/papers/w23944. 
Troianovski, Anton, and Ivan Nechepurenko. 2021. "Belarus Forces Down Plane to Seize Dissident; Europe Sees 'State Hijacking." New York Times, May 24, 2021.

Voice of Belarus. 2020. “Golos Platform Presents the Final Report on the Presidential Election.” August 20, 2020. https:// www.voiceofbelarus.com/golos-final-election-report/. (Accessed April 19, 2021.)

Wilson, Andrew. 2016. "Belarus: From a Social Contract to a Security Contract." Journal of Belarusian Studies 8 (1): 78-91.

Cite this article: Bedford, S. 2021. The 2020 Presidential Election in Belarus: Erosion of Authoritarian Stability and Re-politicization of Society. Nationalities Papers 49: 808-819, doi:10.1017/nps.2021.33 